\title{
ARABICA COFFEE CULTIVARS IN DIFFERENT WATER REGIMES IN THE CENTRAL CERRADO REGION
}

\author{
Adriano Delly Veiga ${ }^{1}$, Gustavo Costa Rodrigues ${ }^{2}$, Omar Cruz Rocha ${ }^{3}$, Gabriel Ferreira Bartholo ${ }^{4}$, \\ Antônio Fernando Guerra ${ }^{5}$, Thiago Paulo da Silva ${ }^{6}$
}

(Received: May 28, 2019; accepted: July 08, 2019)

\begin{abstract}
Phenotypic characterization of coffee cultivars under an irrigation system, as well as adaptability to controlled water stress, aiming at flowering uniformity, high yield and grain quality, plays an important role in coffee production in the cerrado areas. A field trial was carried out aiming to evaluate the agronomic performance of arabica coffee cultivars under different water regimes, using center pivot irrigation: irrigation throughout the year (WR1); suspended at the end of June for 40 days until leaf water potential reached -1.5 MPa (WR2); suspended at the end of June for 70 days until leaf water potential reached -2.3 $\mathrm{MPa}$ (WR3); suspended at the end of June for 100 days until leaf water potential reached -3.4 MPa (WR4); and a non-irrigated regime (WR5). The following traits were analyzed: plant height, stem diameter, canopy projection, number of plagiotropic branches, coffee grain yield, percentage of fruit in the cherry stage, and sieve retention percentages. Higher yield, plant growth, and percentage of fruit in the cherry stage are observed in the water regime with seventy days of controlled water stress (WR3). The Obatã IAC 1669-20 cultivar exhibits high yield and plant growth values in an irrigated system, and Catuaí Amarelo IAC 86 stands out in the non-irrigated system. For these genotypes, the coffee grain yield is most highly correlated with number of reproductive branches.
\end{abstract}

Index terms: Adaptability, yield, vegetative growth, water stress.

\section{CULTIVARES DE CAFÉ ARÁBICA EM DIFERENTES REGIMES HÍDRICOS NO CERRADO CENTRAL}

\begin{abstract}
RESUMO: A caracterização fenotípica de cultivares sob sistema irrigado, bem como adaptabilidade ao uso de suspensão da irrigação visando uniformização da florada, alta produtividade e qualidade de grãos, torna-se importante para a produção da cultura em condições do cerrado. Com objetivo de avaliar desempenho agronômico de cultivares de café arábica em diferentes condições hídricas no cerrado central, foram instalados experimentos em regimes hídricos sob pivô central: aplicação de água durante todo ano (RH1); suspensão da irrigação ao final de junho por 40 dias, atingindo -1,5 MPa (RH2); suspensão da irrigação ao final de junho por cerca 70 dias, atingindo -2,3 Mpa (RH3); suspensão da irrigação ao final de junho por cerca 100 dias, atingindo -3,4 Mpa (RH4) e um regime de sequeiro (RH5). As características avaliadas foram: altura de plantas, diâmetro de caule, projeção da copa, número de ramos plagiotrópicos, produtividade em sacas de $60 \mathrm{~kg}$ de café beneficiado/ha, porcentagem de frutos cerejas e percentual de retenção em peneiras. Maiores produtividades, crescimento vegetativo e percentagem de frutos cerejas são observados no regime hídrico com uso de estresse controlado por cerca de 70 dias. A cultivar Obatã IAC 1669-20 apresenta altos valores de produtividade e bom crescimento vegetativo em condições irrigadas e a cultivar Catuaí Amarelo IAC 86 destaca-se na condição de sequeiro. Para os genótipos avaliados, a produtividade dos grãos possui maior correlação positiva com número de ramos plagiotrópicos.
\end{abstract}

Termos para indexação: Adaptabilidade, produtividade, crescimento vegetativo, estresse hídrico.

\section{INTRODUCTION}

Coffee (Coffea sp.) belongs to the Rubiacea family and is widely distributed and grown in tropical regions. Coffea arabica and Coffea canephora are the species most grown and most economically important. Brazil is the country that most produces and exports coffee in the world, with estimated production in 2019 of up to 52 million bags of hulled coffee grains; approximately
$70 \%$ of this amount is represented by arabica coffee. The arabica coffee crop area is around 1.74 million hectares, with $86 \%$ in production and the remainder still in formation (Conab, 2019).

In Brazil, arabica coffee was initially grown and developed in regions without water deficit in critical periods of the crop. However, with the expansion of agriculture into areas of Cerrado (Brazilian tropical savanna) soils, associated with

\footnotetext{
1,6Embrapa Cerrados - Rod. BR 020 km 18 - Planaltina - DF - 73.310-970 - adriano.veiga@embrapa.br, thiagopaulodasilva@hotmail.com ${ }^{2}$ Embrapa Informática Agropecuária - Av. André Tosello n. 209 - Campus Unicamp - Campinas - SP - 13.083-886 gustavo.rodrigues@embrapa.br

${ }^{3,4,5}$ Embrapa Café - Parque Estação Biológica - Av. W3 norte - Brasília - DF - 70.770-901 - omar.rocha@embrapa.br, gabriel.bartholo@colaborador.embrapa.br, antonio.guerra@embrapa.br
} 
irrigation, this crop has expanded to other areas, such as the Triangle region and northeast region of Minas Gerais, the west of Bahia, the state of Goiás, and the Distrito Federal.

The seasonal growth fluctuations in coffee plants have been studied in some producing regions. It has been observed that for latitudes higher than $15^{\circ} \mathrm{S}$, the greatest vegetative growth occurs with longer and warmer days, as well as with higher precipitation, whereas the lower vegetative growth rates were observed in the colder months with shorter days. Beyond that, the Coffee arabica low growth phase seems to occur at field temperatures lower than $14^{\circ} \mathrm{C}$ (Partelli et al. 2010). The authors state that branches growth patterns appeared to be similar, but the plagiotropic branches of different ages presented different rates in the same period of the year, indicating that seasonal growth studies should not be based on a single branch group with the same age.

In non-equatorial regions, shoot growth is generally slow in the fall/winter, during the dry and cold period, and fast in the spring/summer period, coinciding with beginning of rainy period, with the increase in temperature and in length of daylight period (Rena and Maestri, 1987).

Irrigation has allowed yield increases, both in regions where water deficit coincides with essential stages in the formation and production cycle (Grenho 2007), as well as in regions suitable for crop (Scalco et al., 2011). Considering the advance obtained from development of crops, the vast majority adapted to the dryland crop systems under specific edaphic and climatic conditions, it becomes necessary to study the phenotypic performance of these crops under irrigated cropping system. In addition, coffee plants should be studied for adaptability to the use of suspension of irrigation for the purpose of making flowering more uniform and for greater production of coffee in cherry stage (Guerra et al., 2005; Silva et al., 2009).

Studies regarding plant growth in different coffee varieties can contribute to identify intense or reduced growth phases, associating them with strategies to rationalize the use of inputs and the use of irrigation in areas where it is necessary to supply water, as well as understand the interactions between climate and the coffee plant. Little information is available regarding plant growth and its correlation with yield, above all in irrigated coffee fields, for different arabica coffee cultivars grown in different regions of the country and probably with differential responses under the same growing conditions.
The aim in this study was to evaluate plant growth, yield, grain maturation and sieve retention of arabica coffee cultivars, grown under different water regimes, in the central cerrado conditions.

\section{MATERIAL AND METHODS}

The study was performed at Embrapa Cerrados, Planaltina-DF $\left(15^{\circ} 34^{\prime} 30^{\prime \prime} \mathrm{S}\right.$ and $47^{\circ} 42^{\prime} 30^{\prime \prime} \mathrm{W}$, at an altitude of $\left.1,000 \mathrm{~m}\right)$. According to Köppen classification, the climate is Aw type, rainy tropical with dry winter, mean annual rainfall of $1200 \mathrm{~mm}$, and mean annual temperature of $22^{\circ} \mathrm{C}$. The soil in the experimental area was classified as a dystrophic dark red latosol, with a clayey texture.

Trials were set up in December 2007 in an 8-ha area irrigated by center pivot and another adjacent $2^{\text {-ha }}$ area without use of irrigation. In the irrigated area, a different water regime (WR) was established in each quadrant of the center pivot area, differentiated by increasing levels of water deficit for evaluation of uniform flowering, under the following regimes: application of irrigation water throughout the year, with watering time (WR1); irrigated with suspension for around 40 days from the end of June (WR2); irrigated with suspension for around 70 days from the end of June (WR3); irrigated with suspension for around 100 days from the end of June, or until rain induced flowering (WR4); and a non-irrigated regime (WR5). In the irrigated water regimes, the criterion of irrigation management was soil water balance, based on the Cerrado Irrigation Monitoring System, which supplied information to determine the water amount, the interval, and the time of irrigation.

The cultivars used in the study within each water regime were Iapar 59, Catuaí Amarelo IAC 86, Catuaí Vermelho IAC 99, IBC Palma II, Topázio MG 1190, Obatã IAC 1669-20, Rubi MG1192, Acaiá IAC 474, Sabiá Tardio, Catuaí Vermelho IAC 144, and Icatu Colombiano. The genotypes were planted at a spacing of $3.5 \mathrm{~m}$ between rows and $0.75 \mathrm{~m}$ between plants; a plot consisted of 20 plants, using the six center plants for data collection.

All the treatments were fertilized annually with $300 \mathrm{~kg}$ of $\mathrm{P}_{2} \mathrm{O}_{5} / \mathrm{ha}(2 / 3$ in September and 1/3 in December), $450 \mathrm{~kg}$ of $\mathrm{N}$ and $\mathrm{K}_{2} \mathrm{O} \cdot \mathrm{ha}^{-1}$ (divided into four applications, with the first performed in September and the others beginning in December), and $100 \mathrm{~kg}$. ha ${ }^{-1}$ FTE (BR12) for micronutrients, applied a single time in December. Mechanical and chemical control of weeds and chemical control of pests and diseases were carried out. 
The characteristics evaluated were plant height, measured in meters after harvest from the base of the plants to the apical bud of the stem; stem diameter, measured in millimeters using a caliper rule; canopy projection, measured in meters at approximately one meter from the soil in a transverse direction to the crop row; number of plagiotropic branches, counting all the producing branches on vertical branch; yield, obtained from six plants used for data collection per plot, and expressed in $60-\mathrm{kg}$ bags of hulled coffee per hectare (bag. ha ${ }^{-1}$ ); sieve retention, $300 \mathrm{~g}$ of sample were used, classifying grains in interleaved sieves, for flat grains (numbers 14 to 19) and peaberry grains (numbers 9 to 13). The retention percentage of each sieve was evaluated individually, calculating the sum of the sieves above 16; coffee fruit maturation, after the fruit was washed manually to remove impurities and separated by density, the percentages of fruit in the cherry and unripe stages were noted.

The data represent evaluations of the period from 2010 to 2014. The experimental design used was randomized blocks with three replicates, and each useful plot consisted of six plants. For data analysis, the water regimes and the cultivars were considered as sources of variation, and combined analysis of five crop seasons was carried out through of the statistical software SISVAR (Ferreira, 2011) and the means were clustered by the Scott-Knott test at 5\% probability. The means of the response variables were correlated using the Proc Corr procedure of the statistical program SAS 9.4 (SAS Institute, 2013).

\section{RESULTS AND DISCUSSION}

The results of analysis of variance for coffee grain yield and growth traits showed significance for the main individual sources of variation. The blocks used as replicates, and the interaction (Year x Cultivar) were not significant for canopy projection, plant height and orthotropic branch diameter.

Considering only the effect of the water regime on coffee grain yield, the regimes with irrigation were significantly superior to the dryland management system (Figure 1). Greater yields were observed for the cultivars managed with suspension of irrigation for around 70 days, until the water potential reached around -2.3 Mpa (WR3).

In WR3, through management with controlled water stress, improvement in yield may be related to better filling of coffee grains, due to flowering uniformity and reduced losses in dry coffee fruit arising from uneven flowering, which may occur when the crop receives water throughout the year. In addition, with use of this technology, water and energy use can be reduced by $33 \%$, and cherry coffee fruit ready to harvest can be increased by $30 \%$. This can increase the potential for specialty coffees production, which achieve a better price on the market (Guerra et al., 2005).

The difference of $4 \mathrm{bag} / \mathrm{ha}$ more in WR3 (mean of 49 bags) compared to the water regime with use of irrigation without suspension may be significant in large production areas, in addition to the possibility of adding value and income. As an example of studies in areas of technology validation, Grenho (2007) found mean yields of up to $74.13 \mathrm{bag} / \mathrm{ha}$ and percentage of cherry fruit of up to $72 \%$ in western Bahia, for five cultivars studied. The cultivar Catucaí Amarelo was highest yielding under the conditions evaluated. The values obtained in the present study included cultivars with low adaptability to environmental conditions and to the management system, in this way lower mean yield in analysis of the cultivars in each water regime was found. In commercial areas with use of high production technology, higher mean values were obtained when only cultivars more adapted and recommended for the growing area were used.

Silva et al. (2009) evaluated the effect of controlled water deficit on the uniformity and yield of coffee, in São Paulo state areas and found that the use of 60 days of suspension of irrigation was effective for providing higher yield per plant and higher percentages of fruit in the cherry stage, with water potentials from -1.1 to -1.6 MPa. The autors also found that for the non-irrigated treatment, a smaller number of flowers, lower plant yield, and a smaller number of pinheads were observed. For continuously irrigated plants, a greater number of flowers and a greater amount of up ripe fruit were observed.

Within WR1, one of the water regimes with higher yields, the cultivars Topázio MG 1190 and Obatã IAC 1669-20 were significantly superior, with mean values greater than $56 \mathrm{bag} / \mathrm{ha}$, and within WR3, the cultivar Obatã was superior, with a mean greater than $57 \mathrm{bag} / \mathrm{ha}$ (Figures 2 and 3). In these two regimes, the cultivar IBC Palma II had low plant vigor and worse yield results, well below the others evaluated. 


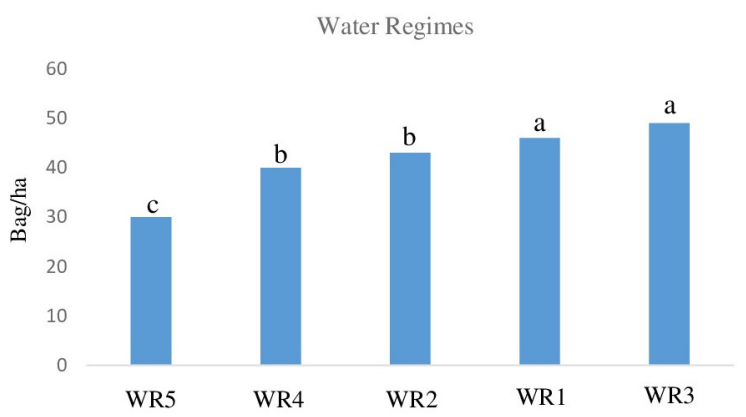

FIGURE 1 - Coffee grain yield (bags/ha) considering different water regimes: WR5 (non-irrigated regime); WR4 (water suspended for 100 days); WR2 (water suspended for 40 days); WR1 (irrigation throughout the year); and WR3 (water suspended for 70 days). Mean values followed by the same letter belong to the same cluster by the Scott Knott test.

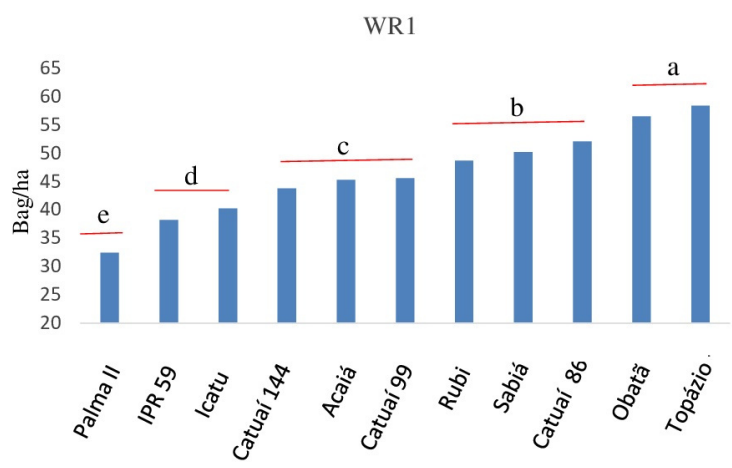

FIGURE 2 - Coffee grain yield (bag/ha) of the arabica coffee cultivars under the water regime of irrigation throughout the year (WR1). Mean values followed by the same letter belong to the same cluster by the Scott Knott test.

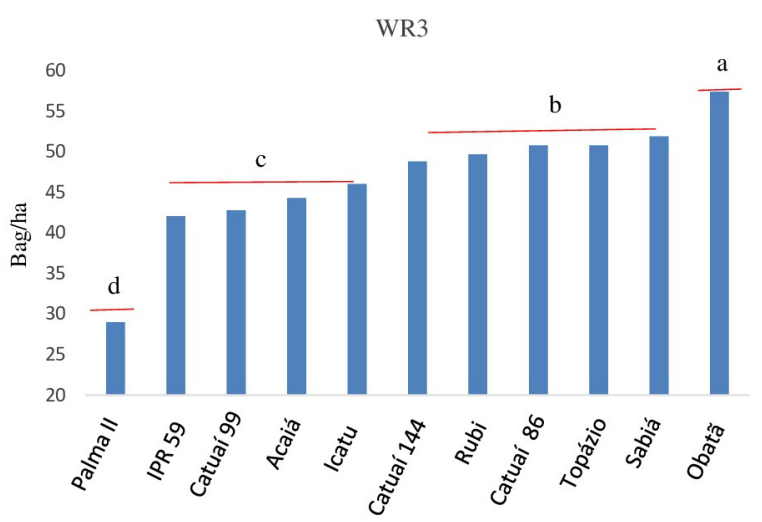

FIGURE 3 - Coffee grain yield (bag/ha) of the arabica coffee cultivars under the water regime of suspension of irrigation for around 70 days (WR3). Mean values followed by the same letter belong to the same cluster by the Scott Knott test. 
In Cerrado regions, yields are higher than the national average due to the use of modern coffee growing methods, with appropriate use of irrigation, mechanization, and customized and balanced fertilization. This biome can be described as having favorable climate conditions, especially at harvest time, when climate is dry and humidity is low, avoiding possible risks and problems with fruit fermentation. In addition, mean temperatures are in an ideal range, with a greater difference in thermal amplitudes, a defined water regime, and, most importantly, a high number of sunlight hours (Fernandes, Partelli and Golynski, 2012).

In non-irrigated conditions, yield values were below those found under the other water regimes, with an overall mean of $29 \mathrm{bag} / \mathrm{ha}$. Three groups of cultivars were observed in means testing, with mean values ranging from 40 bags for Catuaí Amarelo IAC 86 to 33.7 for the cultivar Sabiá Tardio, within the group with higher values (Figure 4). Under this production and management condition, the cultivars Obatã IAC 1669-20 and Rubi MG1192, which had significant yields under water regimes 1 and 3, are notable for their decline in values and position in relation to the other genotypes.

Under non-irrigated regime, the cultivar Catuaí Amarelo IAC 86 stood out in absolute values, which appears to show better adaptability in relation to the other cultivars under the conditions of the dryland production system, in which the cultivar was released in 1972 by the Instituto Agronômico de Campinas. This cultivar has Mundo Novo IAC 374-19 and Caturra IAC 476-11 as parental lines (Setotaw et al., 2013).

Some plants have developed mechanisms capable of reducing the effects of lack of water in the soil, which can be transmitted genetically such as increase of the root system, reduction of leaf area, osmotic adjustment, stomatal closure, among others (Taiz and Zeiger, 2009). Coffee plants retain high leaf moisture content under dehydration conditions and are considered more water conserving species than species tolerant to water deficit, which may be attributed to low elasticity of the cell wall and/or to efficient stomatal control in transpiration (Da Matta et al., 2002).

Results based in yield, in different water regimes, show the cultivar Obatã IAC 1669-20 as a heat tolerant genotype, though susceptible to drought, thus recommended for the Cerrado biome with use of an irrigation system. In view of the constant climate changes observed in recent years, development of cultivars with greater tolerance to abiotic stresses and later evaluation of adaptability become a priority for coffee cultivation. It is of fundamental importance to include this characteristic in coffee plant breeding programs (Da Matta, 2004).

In relation to plant growth of the cultivars, for all the different characteristics evaluated, significant effects were observed both for individual sources of variation and for interactions. Considering only the effect of the different water regimes, just as observed for coffee grain yield, superior mean values were found for plants grown in water regimes with suspension of irrigation for 70 days (WR3) and with irrigation throughout the year, as can be seen for plant height and number of plagiotropic branches (NPB) (Figure 5).

Suspension of irrigation can lead to an increase in growth of orthotropic and plagiotropic branches after resumption of the irrigation, designated as compensatory growth. Thus, higher yield in the treatments with the use of controlled water stress for around 70 days (WR3) is because of better filling of coffee fruit due to uniformity of maturation, as well as greater vegetative growth of the plants. This was also observed in other studies in the same experimental area, (Guerra et al., 2005).

Considering the response of the varieties under the different water regimes, different responses were found due to the genetic factor, as in the case of the cultivar Acaiá IAC 474, which exhibited high values of canopy projection under all water regimes, as well water supply, as in the case of the cultivar Obatã IAC 1669-20. This cultivar exhibited a decline in values as the amount of water was reduced, as examples within regimes 1, 3 and 5 (Figure 6). This corroborates the response of this same cultivar in relation to the decline in its coffee grain yield, under the non-irrigated regime, showing the need for recommendation of an irrigation system.

Under the same environmental conditions, a study was carried out with the Rubi MG1192 cultivar, evaluating initial plant growth in relation to the use of irrigation and treatments with fertilization. Irrigation did not prevent the reduction of growth during the winter, which coincided with greater amplitudes in air temperature and low relative humidity. In addition to showing a significant effect in coffee growth, generating more vigorous plants, irrigation anticipated rapid growth of the plants compared to those in the nonirrigated regime (Nazareno et al., 2003). 


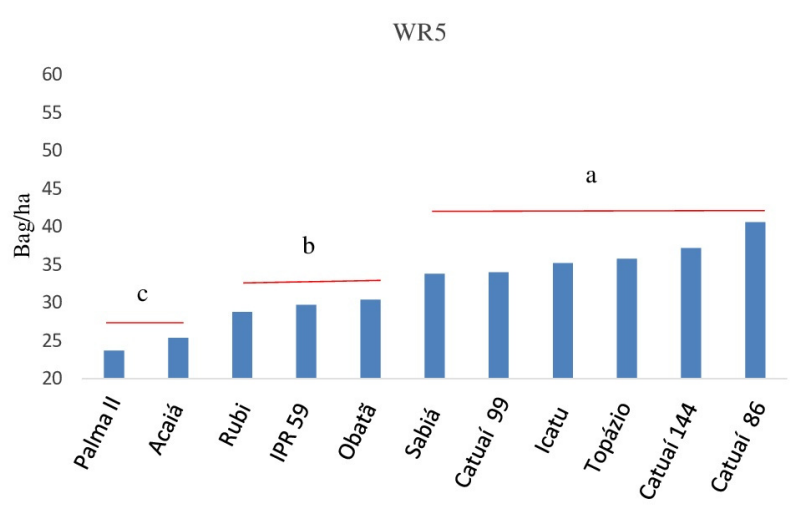

FIGURE 4 - Coffee grain yield (bag/ha) of the arabica coffee cultivars under non-irrigated water regime (WR5). Mean values followed by the same letter belong to the same cluster by the Scott Knott test.

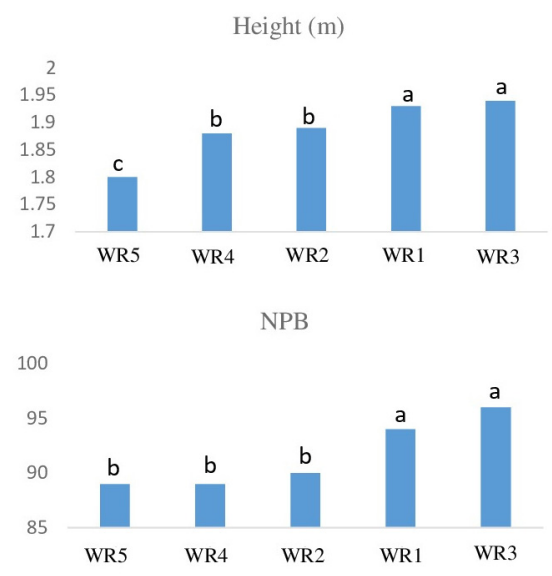

FIGURE 5 - Plant height (m) and number of plagiotropic branches (NPB) according to different water regimes: WR5 (non-irrigated regime); WR4 (water suspended for 100 days); WR2 (water suspended for 40 days); WR1 (irrigation throughout the year); and WR3 (water suspended for 70 days). Mean values followed by the same letter belong to the same cluster by the Scott Knott test.

According to Ferreira et al. (2013), the growth rate of the branches undergoes seasonal variation throughout the year, regardless of irrigation. Under minimum air temperatures below $17^{\circ} \mathrm{C}$ and water deficit, there is reduction in growth rate under the environmental conditions of the Cerrado in the state of Goiás.

In the diverse coffee production regions, growth is also reduced in the cold and dry period and accelerated in the hot and humid period. The periodicity of vegetative development may also be affected by factors such as the amplitude of air temperature and by reduction in stomatal conductance (Nazareno et al., 2003).

The data in water regimes 1 (irrigation throughout the year), 3 (water suspended for 70 days), and 5 (non-irrigated regime) stood out for the response variables of sieve retention of coffee grains and fruit maturation. After checking analysis of variance for percentage of coffee grains classified in sieves above 16, interaction between the water regimes and the cultivars was found. For these traits, by reinforcing the values for each cultivar, a data table was used. Table 1 shows the mean values observed for the highest yielding irrigated water regimes and the non-irrigated regime. Significant differences were not observed among the water regimes, and the differences within the regimes may be related to the genetic factor. Cultivars such as Acaiá IAC 474, Catuaí Amarelo IAC 86, and Rubi MG1192 did not show reduction in values, even when produced without the use of irrigation. 

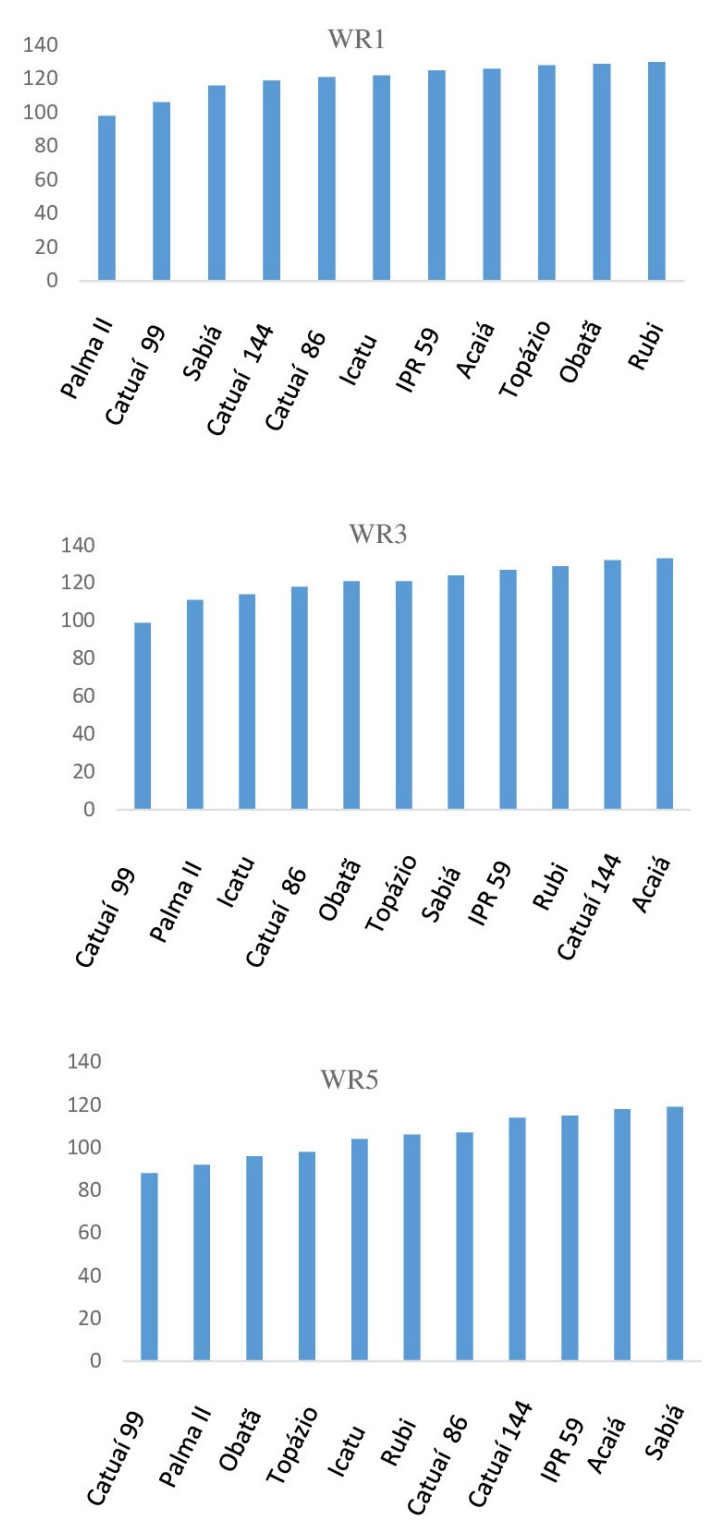

FIGURE 6 - Canopy projection $(\mathrm{cm})$ of the arabica coffee cultivars in the water regimes WR1, WR3, and WR5.

Separation of the coffee grains through sieve classification leads to improvement in quality of the final product, due to greater uniformity. Coffee grains with different sizes, especially smaller sizes, can lead to rapid and uneven roasting, impairing flavor and aroma.

After checking analysis of variance, the values of percentage of cherry fruit in the water regime with use of stress controlled for around 70 days (WR3) were greater than in the water regime that used irrigation throughout the year, with a watering time (WR1) and the non-irrigated regime (WR5). The WR3 regime showed a mean of $72 \%$ cherry fruit and $22 \%$ unripe fruit, and the WR1 showed $42 \%$ cherry fruit and $48 \%$ unripe fruit. Within the WR3, different values were observed for the cultivars in relation to fruit maturation and adaptation to use of controlled water stress. The cultivars Iapar 59 and Catuaí 86 had percentages of cherry fruit above $80 \%$ (Table 1 ).

In a study carried out by Souza et al. (2014) with clones of canefora conilon, in the Espírito Santo conditions, verified a higher percentage of mature fruits and a lower percentage of dry fruits in relation to the irrigated management, varying in the response of the genotypes. 
TABLE 1 - Percentages of coffee grains retained in sieves greater than $16(\% \mathrm{P})$ and percentages of cherry fruit $(\% \mathrm{C})$ in the water regimes WR1, WR3, and WR5.

\begin{tabular}{lcccccc}
\hline Cultivar & WR1 \% & WR3 $\%$ & WR5 $\%$ & WR1 $\%$ & WR3 $\%$ & WR5 \% \\
& $P$ & P & P & C & C & C \\
\hline Icatu & $44 \mathrm{~b}$ & $46 \mathrm{~b}$ & $34 \mathrm{c}$ & $60 \mathrm{a}$ & $71 \mathrm{~b}$ & $35 \mathrm{~b}$ \\
Catuaí 144 & $55 \mathrm{a}$ & $51 \mathrm{a}$ & $49 \mathrm{~b}$ & $43 \mathrm{~b}$ & $63 \mathrm{~b}$ & $51 \mathrm{a}$ \\
Sabiá & $43 \mathrm{~b}$ & $31 \mathrm{~b}$ & $41 \mathrm{c}$ & $44 \mathrm{~b}$ & $78 \mathrm{a}$ & $50 \mathrm{a}$ \\
Acaiá & $65 \mathrm{a}$ & $61 \mathrm{a}$ & $66 \mathrm{a}$ & $30 \mathrm{c}$ & $77 \mathrm{a}$ & $41 \mathrm{~b}$ \\
Rubi & $51 \mathrm{~b}$ & $52 \mathrm{a}$ & $52 \mathrm{~b}$ & $24 \mathrm{c}$ & $69 \mathrm{~b}$ & $18 \mathrm{c}$ \\
Obatã & $59 \mathrm{a}$ & $55 \mathrm{a}$ & $55 \mathrm{a}$ & $54 \mathrm{a}$ & $69 \mathrm{~b}$ & $46 \mathrm{a}$ \\
Topázio & $49 \mathrm{~b}$ & $45 \mathrm{~b}$ & $39 \mathrm{c}$ & $28 \mathrm{c}$ & $66 \mathrm{~b}$ & $33 \mathrm{~b}$ \\
Palma II & $52 \mathrm{~b}$ & $49 \mathrm{a}$ & $49 \mathrm{~b}$ & $28 \mathrm{c}$ & $60 \mathrm{~b}$ & $17 \mathrm{c}$ \\
Catuaí 99 & $56 \mathrm{a}$ & $54 \mathrm{a}$ & $50 \mathrm{~b}$ & $49 \mathrm{~b}$ & $71 \mathrm{~b}$ & $26 \mathrm{c}$ \\
Catuaí 86 & $54 \mathrm{a}$ & $54 \mathrm{a}$ & $57 \mathrm{a}$ & $51 \mathrm{a}$ & $81 \mathrm{a}$ & $36 \mathrm{~b}$ \\
Iapar 59 & $62 \mathrm{a}$ & $59 \mathrm{a}$ & $58 \mathrm{a}$ & $53 \mathrm{a}$ & $82 \mathrm{a}$ & $42 \mathrm{~b}$ \\
Mean & $54 \mathrm{a}$ & $51 \mathrm{a}$ & $50 \mathrm{a}$ & $42 \mathrm{~b}$ & $72 \mathrm{a}$ & $35 \mathrm{c}$
\end{tabular}

*Mean values followed by the same lowercase letter in the column belong to the same cluster by the Scott Knott test. On the last line of means, the values of $\% \mathrm{P}$ were analyzed separately from $\% \mathrm{C}$.

The use of this management practice and technology, with imposition of controlled water deficits for control of flowering, is dependent on rain distribution in the dry season. The initial period of flowering generally occurs in a similar manner, with differences in the uniformity and number of subsequent flowerings.

For the environmental conditions of the study, for the genotypes evaluated, greater phenotypic correlation was found for coffee grain yield with the number of plagiotropic branches (Table 2). When all the water regimes studied are considered, the highest values of correlation were observed, in a highly significant way, between plant height and canopy projection, and between plant height and stem diameter.

For correlations among variables, only considering the regime with use of water stress controlled for 70 days, higher values were observed (Table 3), indicating development of different parts of the plant in a similar and also intense way. This result may be related to the management practices adopted, under ideal conditions of light, temperature, and supply of water and nutrients, adapted to an irrigated production system, in the central Cerrado region of Brazil.

Teixeira et al. (2013) also found high values of correlation between plant height and stem diameter, as well as between plant height and length of the first plagiotropic branch, when they evaluated, at twelve months of age, cultivars, F1 hybrids, and accessions introduced from other countries under tropical climate conditions. Assis et al. (2014), under the conditions of the South of Minas Gerais, found higher yields in irrigated regimes in a densely planted system, as well as higher correlations between plant height and yield in two crop seasons, and between number of plagiotropic branches and yield only in a first crop season. 
TABLE 2 - Estimate of the coefficients of correlation between the vegetative traits of plant height, canopy projection (CP), stem diameter, number of plagiotropic branches (NPB), and coffee grain yield of the cultivars of Coffea arabica, considering all the water regimes.

\begin{tabular}{llllll}
\hline Variable & Height & CP & Diam. & NPB & Yield \\
\hline Height & 1.00 & $0.87^{*}$ & $0.77^{*}$ & $0.65^{*}$ & 0.24 \\
CP & & 1.00 & $0.58^{*}$ & $0.71^{*}$ & 0.43 \\
Diam. & & 1.00 & 0.10 & 0.02 \\
NPB & & & 1.00 & $0.58^{*}$ \\
Yield & & & & 1.00 \\
\hline
\end{tabular}

TABLE 3 - Estimate of the coefficients of correlation between the vegetative traits of plant height, canopy projection (CP), stem diameter, number of plagiotropic branches (NPB), and coffee grain yield of the cultivars of Coffea arabica, considering WR3.

\begin{tabular}{llllll}
\hline Variable & Height & CP & Diam & NPB & Yield \\
\hline Height & 1.00 & $0.92^{*}$ & $0.81^{*}$ & $0.86^{*}$ & 0.29 \\
CP & & 1.00 & $0.58^{*}$ & $0.91^{*}$ & 0.47 \\
Diam & & 1.00 & 0.44 & 0.08 \\
NPB & & & 1.00 & $0.64^{*}$ \\
Yield & & & & 1.00 \\
\hline
\end{tabular}

\section{CONCLUSIONS}

Higher yields, vegetative growth, and percentage of cherry fruit are observed under the water regime with water stress controlled for 70 days. The cultivar Obatã IAC 1669-20 shows high yield values and good vegetative growth, under irrigated conditions, and the cultivar Catuai Amarelo IAC 86 stands out under non-irrigated conditions.

For these genotypes, the coffee grain yield is most highly correlated with number of reproductive branches, and for these traits, the highest value of correlation is between plant height and canopy projection.

\section{REFERENCES}

ASSIS, G. A. S. et al. Correlação entre crescimento e produtividade do cafeeiro em função do regime hídrico e densidade de plantio. Bioscience Journal, Uberlândia, v. 30, n. 3, p. 666-676, 2014.

COMPANHIA NACIONAL DE ABASTECIMENTO. Acompanhamento da safra brasileira: café, v.6 - Safra 2019, n.1 - Primeiro Levantamento, Brasília, p.1-62, janeiro 2019.
DA MATTA, F. M. Exploring drought tolerance in coffee: a physiological approach with some insights for plant breeding. Brazilian Journal of Plant Physiology, Campos dos Goytacazes, v.16, p.1-6, 2004.

DA MATTA, F. M. et al. Limitations to photosynthesis in Coffea canephora as a result of nitrogen and water availability. Journal of Plant Physiology, 159:975-981, 2002.

FERNANDES, A. L. F.; PARTELLI, F. L.; GOLYNSKI, A. A moderna cafeicultura dos cerrados brasileiros. Pesquisa Agropecuária Tropical, Goiânia, v. 42, n. 2 , p. 231-240, 2012.

FERREIRA, E. P. B. Crescimento vegetativo de Coffea arabica L. influenciado por irrigação e fatores climáticos no Cerrado Goiano. Semina: Ciências Agrárias, Londrina, v. 34, n. 6, suplemento 1, p. 32353244, 2013.

FERREIRA, D. F. Sisvar: a computer statistical analysis system. Ciência e Agrotecnologia Lavras, v. 35, n.6, p. 1039-1042, 2011.

GRENHO, A. I. S. (2007). Influência do estresse hídrico na produtividade e qualidade de cinco genótipos de café. 30p. Dissertação (Mestrado em Ciências Agrárias) - Universidade de Brasília, Brasília, DF. 
GUERRA, A. F.; ROCHA, O. C.; RODRIGUES, G. C. Manejo do cafeeiro irrigado no Cerrado com estresse hídrico controlado. ITEM, Irrigação e Tecnologia Moderna, Brasília, n.65/66, p. 42-45, 2005.

NAZARENO, R. B. et al. Crescimento inicial do cafeeiro Rubi em resposta a doses de nitrogênio, fósforo e potássio e a regimes hídricos. Pesquisa Agropecuária Brasileira, Brasília, v. 38, n. 8, p. 903-910, 2003.

RENA, A. B.; MAESTRI, M. Ecofisiologia do cafeeiro. In: Ecofisiologia da produção agrícola. Piracicaba: Associação Brasileira para a Pesquisa da Potassa e Fósforo, p.119-147, 1987.

PARTELLI, F. L. et al. Seasonal vegetative growth of different age branches of conilon coffee tree. Semina: Ciências Agrárias, Londrina, v. 31, n. 3, p. 619-626, jul./set. 2010.

SAS INSTITUTE INC. Versão 9.4. Procedures Guide. Cary, NC: SAS Institute Inc, 2013.
SCALCO, M. S. et al. Cultivo irrigado e não irrigado do cafeeiro (Coffea arabica L.) em plantio superadensado. Coffee Science, Lavras, v. 6, n. 3, p. 193-202, 2011.

SILVA, E. A. et al. Influência de déficits hídricos controlados na uniformização do florescimento e produção do cafeeiro em três diferentes condições edafoclimáticas do estado de São Paulo. Bragantia, Campinas, v.68, n.2, p.493-501, 2009.

SETOTAW, T. A. et al. Coefficient of parentage in Coffea arabica L. cultivars grown in Brazil. Crop Science, Madison, vol. 53, n.4, p. 1237-1247, 2013.

SOUZA, J. M. et al. Interrupção da irrigação e maturação dos frutos de café Conilon. Científica, Jaboticabal, v.42, n.2, p.170-177, 2014.

TAIZ, L.; ZEIGER, E. Fisiologia vegetal. 5. ed. Porto Alegre: Artmed, 2009. 719 p.

TEIXEIRA, A. L. et al. Análise de componentes principais em caracteres morfológicos de café arábica em estádio juvenil. Coffee Science, Lavras, v. 8, n. 2, p. $205-210,2013$. 